\title{
INFLUENCE OF THE SOCIO-DEMOGRAPHIC CHARACTERISTICS OF MOTHERS OF CHILDREN AGED 3-10 YEARS ON THEIR AT-HOME SUPPORT OF FRUIT AND VEGETABLE CONSUMPTION*
}

\author{
Barbara Groele ${ }^{1}$, Dominika Gtabska ${ }^{1}$, Krystyna Gutkowska², Dominika Guzek²
}

\author{
${ }^{1}$ Department of Dietetics, Faculty of Human Nutrition and Consumer Sciences, Warsaw University of Life \\ Sciences (SGGW-WULS), Poland \\ ${ }^{2}$ Department of Organization and Consumption Economics, Faculty of Human Nutrition and Consumer \\ Sciences, Warsaw University of Life Sciences (SGGW-WULS), Poland
}

\begin{abstract}
Background. The inadequate fruit and vegetable intake is common for adults and children, while for children increasing intake is especially important, as intake during childhood predicts future adulthood intake.

Objective. The aim of the study was to assess influence of the socio-demographic characteristics of mothers on their athome support of fruit and vegetable consumption in the national Polish sample.

Material and methods. The study was conducted in a national representative sample of Polish mothers of children aged 3-10 ( $\mathrm{n}=1200)$, who were recruited using a random quota sampling (quotas: age, education, region, size of city). They were interviewed using a Computer-Assisted Telephone Interviewing (CATI) method and asked about dietary patterns of their children and their at-home behaviors to support fruit and vegetable consumption, which were afterwards compared in sub-groups stratified for age, educational background, marital status, place of residence, occupational status and total net income in households.

Results. For fruits, mothers with lower level of education, from villages/ smaller towns, with no professional job and lower income, more commonly than others, stated, that no support of consumption is needed, as their children eat fruits with no encouragement. For vegetables, either the same situation as for fruits was observed (for mothers with no professional job and lower income), or mothers more commonly than others declared forcing children to consume (for mothers with the lowest level of education).

Conclusions. The socio-demographic status of mothers, especially level of education, place of residence, professional job and income, are important factors associated with their at-home support of fruit and vegetable consumption for their children. The groups of mothers with lower level of education, from villages/ smaller towns, with no professional job and lower income were indicated as important target groups to provide them knowledge about the recommended fruit and vegetable intake, as well as recommended parenting style.
\end{abstract}

Key words: fruit, vegetables, mothers, child, diet

\section{STRESZCZENIE}

Wprowadzenie. Niedostateczne spożycie owoców i warzyw jest powszechne u dorosłych i dzieci, ale u dzieci zwiększenie spożycia jest szczególnie istotne, gdyż może ono oddziaływać również na późniejsze spożycie w dorosłości.

Cel. Celem badania była ocena wpływu cech socjo-demograficznych matek na ich zachowania promujące spożycie owoców i warzyw w domu przez ich dzieci, w krajowej polskiej próbie.

Material i metody. Badanie przeprowadzono w krajowej reprezentatywnej próbie polskich matek dzieci w wieku 3-10 lat $(\mathrm{n}=1200)$, które rekrutowano $\mathrm{z}$ wykorzystaniem metody doboru losowego kwotowego (kwoty: wiek, wykształcenie, region, wielkość miasta). Wywiad przeprowadzono z wykorzystaniem metody CATI (ang. Computer-Assisted Telephone Interviewing - wspomagany komputerowo wywiad telefoniczny) i zapytano o zachowania żywieniowe dzieci i zachowania matek promujące spożycie owoców i warzyw, które porównano w podgrupach zależnych od wieku, edukacji, stanu cywilnego, miejsca zamieszkania, zatrudnienia, łącznego dochodu netto w gospodarstwie domowym.

Corresponding author: Dominika Głąbska, Department of Dietetics, Faculty of Human Nutrition and Consumer Sciences, Warsaw University of Life Sciences (SGGW-WULS), 159C Nowoursynowska Street, 02-787 Warsaw, Poland, tel.: +48-22-593-71-26, e-mail: dominika_glabska@sggw.pl

*The data gathering was financed by the National Polish Promotion Fund for Fruits and Vegetables Consumption and Polish Association of Juices Producers within funds of the 5xVFJ (5 Portions of Vegetables, Fruit or Juice) national Polish campaign (Project of Agricultural Market Agency, no. PP/004/004/PP-1767/W/2011 financed within the Common Agricultural Policy (CAP), action: Support of promotion and information actions for agricultural products). 
Wyniki. W przypadku owoców, matki z niższym wykształceniem, ze wsi/ małych miast, bezrobotne i o niższym dochodzie, częściej niż pozostałe stwierdzały, że nie muszą promować spożycia u dzieci, bo jedzą one owoce bez zachęty. W przypadku warzyw, obserwowano taką samą sytuację jak dla owoców (matki bezrobotne, o niższym dochodzie), lub matki częściej niż pozostałe stwierdzały, że zmuszają dzieci do spożywania (matki o najniższym wykształceniu).

Wnioski. Cechy socjo-demograficzne matek, szczególnie wykształcenie, miejsce zamieszkania, zatrudnienie i dochód są istotnymi determinantami zachowań promujących spożycie owoców i warzyw w domu przez ich dzieci. Matki o niższym wykształceniu, ze wsi/małych miast, bezrobotne i o niższym dochodzie, to istotne grupy docelowe którym powinna być zapewniona wiedza o rekomendowanym spożyciu owoców i warzyw oraz stylu wychowania.

Słowa kluczowe: owoce, warzywa, matki, dzieci, dieta,

\section{INTRODUCTION}

The World Health Organization (WHO) recommends the daily intake of $400 \mathrm{~g}$ of fruits and vegetables [6]. However, the recent systematic review and dose-response meta-analysis of prospective studies by Aune et al. [2] indicated, that in fact, fruit and vegetable intake is associated with reduced risk of cardiovascular disease, cancer and all-cause mortality, but the even higher intake of 500-800 g should be obtained to observe the positive influence. It is supported by the other statement by WHO which attributes 1.7 million of deaths worldwide $(2.8 \%$ of the total number of deaths) to low fruit and vegetable consumption [33].

In spite of a well-known recommendation of consuming 5 servings of fruits and vegetables a day [23], the inadequate intake is common. It was stated for United States of America, based on the Centers for Disease Control and Prevention (CDC) data that only $12.2 \%$ of inhabitants met fruit intake and $9.3 \%$ met vegetable intake recommendations [20]. Similarly, based on the WHO data, it was indicated, that for European countries, the intake is low especially for western and northern Europe countries, as for majority of them, it is lower than $300 \mathrm{~g}$ per day [32]. For Poland, the inadequate fruit and vegetable intake is observed for children [14], university students [5], including those of medical universities [16] and adults [15].

In the case of children, obtaining the adequate intake of fruits and vegetables is especially essential, and it is stated that all the programs aiming at obtaining the indicated goal are a good investment in terms of cost benefit ratio, due to future health-related effects [24]. It results from the fact that the fruit and vegetable exposure and higher intake during childhood are associated with the higher fruit and vegetable intake in the future [22]. However, obtaining the increased intake of fruits and vegetables is for children challenging [30], as there are a lot of factors which influence the intake, including those associated with parents [17].

Also in Poland, it was stated that the food preference of mothers and their dietary habits influence the fruit [9] and vegetable intake of their children [10].
However, the other important area are so-called parenting practices, associated with various level of their control and involvement, that also influence the dietary habits of child [31]. Specifically, the support of fruit and vegetable intake at home may be expressed by various parenting practices, associated with either encouragement or forcing child, at the various levels of involvement [4]. The aim of the presented study was to assess the influence of the socio-demographic characteristics of mothers of children aged 3-10 years on their at-home support of fruit and vegetable consumption in the national Polish sample.

\section{MATERIAL AND METHODS}

The study was conducted according the guidelines of the Declaration of Helsinki, while all the participants provided their informed consent to participate in the study. All the procedures were approved by the Ethics Committee of the Faculty of Human Nutrition and Consumer Sciences of the Warsaw University of Life Sciences.

The study was conducted in a national representative sample of Polish mothers of children aged 3-10 years $(\mathrm{n}=1200)$, who were recruited using a random quota sampling method (quotas for age, education, place of residence, region of Poland and size of the city for the place of residence), from the general Polish population, as in the previously published own studies [9-10].

The procedure of recruitment was conducted by the agency assessing the public opinion and perception, while the following criteria were applied:

Inclusion criteria:

- women,

- age: $25-45$ years,

- living in Poland,

- mother of child/ children aged 3-10 years.

Exclusion criteria:

- no informed consent to participate in the study registered as an audio file during the interviewing,

- any missing data in the questionnaire (the only question that was allowed to be not answered was associated with the total net income in the household). 
The participants were interviewed using a method of Computer-Assisted Telephone Interviewing (CATI). If mother declared having more than one child aged 3-10, she was asked to select one of them and answer only about this one specific child. They were asked about dietary patterns of their children (proxy reporting) and their own at-home behaviors to support fruit and vegetable consumption, by a two closed-ended questions about:

(1) At-home support of fruit consumption, with the following answers to choose one:

a) Child always wants to eat fruits with no encouragement

b) Sometimes child wants to eat fruits with no encouragement and sometimes I must encourage

c) I always encourage child to eat fruits

d) Sometimes I encourage child to eat fruits and sometimes I must even force

e) I always force child to eat fruits

(2) At-home support of vegetable consumption, with the following answers to choose one:

a) Child always wants to eat vegetables with no encouragement

b) Sometimes child wants to eat vegetables with no encouragement and sometimes I must encourage

c) I always encourage child to eat vegetables

d) Sometimes I encourage child to eat vegetables and sometimes I must even force

e) I always force child to eat vegetables

In spite of the fact that in general questions were about mothers at-home behaviors to support fruit and vegetable consumption of their children, the possible answers to choose one captured not only the behavior of mother, but also the behavior of child (if they eat fruits/ vegetables even with no encouragement).

Afterwards, the obtained answers were compared in sub-groups that were stratified for age, educational background, marital status, place of residence, occupational status and total net income in households, with the following number of respondents in each group:

- age: aged 25-30 $(n=274)$; aged 30-35 $(n=448)$; aged 35-40 $(\mathrm{n}=333)$, and aged 40-45 $(\mathrm{n}=145)$;

- educational background: primary education $(\mathrm{n}=56)$; vocational qualification $(\mathrm{n}=187)$; secondary education $(\mathrm{n}=470)$; and higher education $(n=487)$;

- marital status: married/in a married-like relationship $(\mathrm{n}=1072)$; single/separated/ divorced/widowed $(n=128)$;

- place of residence: village $(n=501)$; city of up to 100000 inhabitants $(\mathrm{n}=375)$; city of above 100000 inhabitants $(\mathrm{n}=324)$;

- occupational status: any full-time or part-time job $(\mathrm{n}=790)$; no job declared $(\mathrm{n}=410)$;

- total net income in household (only for this question respondents were allowed to not answer and $n=97$ mothers were excluded from this analysis due to lack of answer): lower than 2000 PLN $(\sim 450 €)(\mathrm{n}=307) ; 2000-4000$ PLN $(\sim 450-900 €)(\mathrm{n}=494)$; higher than 4000 PLN $(\sim 900 €)(\mathrm{n}=302)$.

The obtained data were analyzed using $C h i^{2}$ test, while $\mathrm{p} \leq 0.05$ was concluded as statistically significant. The Statgraphics Plus for Windows 5.1 (Statgraphics Technologies Inc., The Plains, VA, USA) software was used.

\section{RESULTS}

The declared mothers at-home support of fruit and vegetable consumption stratified by the age of mother is presented in Table 1. It was stated, that neither for fruit $(p=0.7330)$, nor for vegetable consumption support $(p=0.2396)$, the age of mother was influencing factor.

Table 1. Declared mothers at-home support of fruit and vegetable consumption stratified by the age of mother

\begin{tabular}{|c|c|c|c|c|c|c|}
\hline \multicolumn{2}{|r|}{ Declared behaviour } & $\begin{array}{l}25-30 \text { years } \\
(\mathrm{n}=274)\end{array}$ & $\begin{array}{l}30-35 \text { years } \\
(\mathrm{n}=448)\end{array}$ & $\begin{array}{l}35-40 \text { years } \\
(\mathrm{n}=333)\end{array}$ & $\begin{array}{l}\text { 40-45 years } \\
(\mathrm{n}=145)\end{array}$ & p-Value* \\
\hline \multirow{5}{*}{$\begin{array}{l}\text { Mothers' at-home } \\
\text { support of fruit } \\
\text { consumption }\end{array}$} & $\begin{array}{l}\text { Child always wants to eat fruits } \\
\text { with no encouragement }\end{array}$ & $110(40.1 \%)$ & $166(37.1 \%)$ & $135(40.5 \%)$ & $62(42.8 \%)$ & \multirow{5}{*}{0.7330} \\
\hline & $\begin{array}{l}\text { Sometimes child wants to eat fruits with } \\
\text { no encouragement and I must encourage }\end{array}$ & $118(43.1 \%)$ & $218(48.7 \%)$ & $149(44.7 \%)$ & $66(45.5 \%)$ & \\
\hline & I always encourage child to eat fruits & $29(10.6 \%)$ & $46(10.3 \%)$ & $34(10.2 \%)$ & $8(5.5 \%)$ & \\
\hline & $\begin{array}{l}\text { Sometimes I encourage child to eat fruits } \\
\text { and sometimes I must even force }\end{array}$ & $13(4.7 \%)$ & $14(3.1 \%)$ & $10(3.0 \%)$ & $6(4.1 \%)$ & \\
\hline & I always force child to eat fruits & $4(1.5 \%)$ & $4(0.9 \%)$ & $5(1.5 \%)$ & $3(2.1 \%)$ & \\
\hline \multirow{5}{*}{$\begin{array}{l}\text { Mothers' at-home } \\
\text { support of } \\
\text { vegetable } \\
\text { consumption }\end{array}$} & $\begin{array}{l}\text { Child always wants to eat vegetables } \\
\text { with no encouragement }\end{array}$ & $40(14.6 \%)$ & $49(10.9 \%)$ & $32(9.6 \%)$ & $25(17.2 \%)$ & \multirow{5}{*}{0.2396} \\
\hline & $\begin{array}{c}\text { Sometimes child wants to eat vegetables } \\
\text { with no encouragement and I must } \\
\text { encourage }\end{array}$ & $73(26.6 \%)$ & $139(31.0 \%)$ & $108(32.4 \%)$ & $46(31.7 \%)$ & \\
\hline & I always encourage child to eat vegetables & $101(36.9 \%)$ & $167(37.3 \%)$ & $124(37.2 \%)$ & $54(37.2 \%)$ & \\
\hline & $\begin{array}{l}\text { Sometimes I encourage child to eat } \\
\text { vegetables and I must even force }\end{array}$ & $45(16.4 \%)$ & $74(16.5 \%)$ & $47(14.1 \%)$ & $14(9.7 \%)$ & \\
\hline & I always force child to eat vegetables & $15(5.5 \%)$ & $19(4.2 \%)$ & $22(6.6 \%)$ & $6(4.1 \%)$ & \\
\hline
\end{tabular}

* assessed using $C h i^{2}$ test 
The declared mothers at-home support of fruit and vegetable consumption stratified by the educational background of mother is presented in Table 2. It was stated, that both for fruit $(\mathrm{p}=0.0000)$, and for vegetable consumption support $(p=0.0176)$, the educational background of mother was influencing factor. For the fruit consumption support, mothers with a lower level of education, more commonly than those with the higher education declared lack of any support of fruit consumption due to the fact that it is not needed ("child always wants to eat fruits with no encouragement") ( $45 \%$ for primary education, $51 \%$ for vocational qualification, $43 \%$ for secondary education vs. $31 \%$ for higher education). At the same time, mothers with the higher education more commonly than those with a lower level of education declared that child only sometimes wants to eat fruits with no encouragement, but sometimes she must encourage ( $56 \%$ vs. $39 \%$ for primary education, $33 \%$ for vocational qualification, $42 \%$ for secondary education). For the vegetable consumption support, mothers with a lowest level of education, more commonly than others declared forcing child to consume vegetables (for combined answers indicating forcing sometimes and forcing always: $30 \%$ for primary education vs. $16 \%$ for vocational qualification, $21 \%$ for secondary education, $19 \%$ for higher education). At the same time, they less commonly than others declared that they always encourage child to eat vegetables $25 \%$ for primary education vs. $35 \%$ for vocational qualification, $38 \%$ for secondary education, $39 \%$ for higher education).

Table 2. Declared mothers at-home support of fruit and vegetable consumption stratified by the educational background of mother

\begin{tabular}{|c|c|c|c|c|c|c|}
\hline & Declared behaviour & $\begin{array}{l}\text { Primary } \\
\text { education } \\
(\mathrm{n}=56)\end{array}$ & $\begin{array}{c}\text { Vocational } \\
\text { qualification } \\
(\mathrm{n}=187)\end{array}$ & $\begin{array}{c}\text { Secondary } \\
\text { education } \\
(\mathrm{n}=470)\end{array}$ & $\begin{array}{l}\text { Higher } \\
\text { education } \\
(\mathrm{n}=487)\end{array}$ & p-Value* \\
\hline \multirow{5}{*}{$\begin{array}{l}\text { Mothers' at-home } \\
\text { support of fruit } \\
\text { consumption }\end{array}$} & $\begin{array}{l}\text { Child always wants to eat fruits } \\
\text { with no encouragement }\end{array}$ & $25(44.6 \%)$ & $96(51.3 \%)$ & $201(42.8 \%)$ & $151(31.0 \%)$ & \multirow{5}{*}{0.0000} \\
\hline & $\begin{array}{l}\text { Sometimes child wants to eat fruits with } \\
\text { no encouragement and sometimes I must } \\
\text { encourage }\end{array}$ & $22(39.3 \%)$ & $62(33.2 \%)$ & $196(41.7 \%)$ & $271(55.6 \%)$ & \\
\hline & I always encourage child to eat fruits & $8(14.3 \%)$ & $20(10.7 \%)$ & $42(8.9 \%)$ & $47(9.7 \%)$ & \\
\hline & $\begin{array}{l}\text { Sometimes I encourage child to eat fruits } \\
\text { and sometimes I must even force }\end{array}$ & $0(0.0 \%)$ & $6(3.2 \%)$ & $23(4.9 \%)$ & $14(2.9 \%)$ & \\
\hline & I always force child to eat fruits & $1(1.8 \%)$ & $3(1.6 \%)$ & $8(1.7 \%)$ & $4(0.8 \%)$ & \\
\hline \multirow{5}{*}{$\begin{array}{l}\text { Mothers' at-home } \\
\text { support of } \\
\text { vegetable } \\
\text { consumption }\end{array}$} & $\begin{array}{l}\text { Child always wants to eat vegetables } \\
\text { with no encouragement }\end{array}$ & $7(12.5 \%)$ & $35(18.7 \%)$ & $64(13.6 \%)$ & $40(8.2 \%)$ & \multirow{5}{*}{0.0176} \\
\hline & $\begin{array}{c}\text { Sometimes child wants to eat vegetables } \\
\text { with no encouragement and I must } \\
\text { encourage }\end{array}$ & $18(32.1 \%)$ & $56(29.9 \%)$ & $129(27.4 \%)$ & $163(33.5 \%)$ & \\
\hline & $\begin{array}{c}\text { I always encourage child to eat } \\
\text { vegetables }\end{array}$ & $14(25.0 \%)$ & $65(34.8 \%)$ & $177(37.7 \%)$ & $190(39.0 \%)$ & \\
\hline & $\begin{array}{c}\text { Sometimes I encourage child to eat } \\
\text { vegetables and sometimes I must even } \\
\text { force }\end{array}$ & $12(21.4 \%)$ & $24(12.8 \%)$ & $74(15.7 \%)$ & $70(14.4 \%)$ & \\
\hline & I always force child to eat vegetables & $5(8.9 \%)$ & $7(3.7 \%)$ & $26(5.5 \%)$ & $24(4.9 \%)$ & \\
\hline
\end{tabular}

* assessed using $C h i^{2}$ test

The declared mothers at-home support of fruit and vegetable consumption stratified by the marital status of mother is presented in Table 3. It was stated, that neither for fruit $(\mathrm{p}=0.7483)$, nor for vegetable consumption support $(p=0.2313)$, the marital status of mother was influencing factor.

The declared mothers at-home support of fruit and vegetable consumption stratified by the place of residence of mother is presented in Table 4. It was stated, that for fruit $(\mathrm{p}=0.0025)$, but not for vegetable consumption support $(p=0.5040)$, the place of residence of mother was influencing factor. For the fruit consumption support, mothers from villages and small towns, more commonly than those from big cities declared lack of any support of fruit consumption due to the fact that it is not needed ("child always wants to eat fruits with no encouragement") (44\% for villages, $40 \%$ for small towns vs. $31 \%$ for big cities). At the same time, mothers from big cities more commonly than others declared that child only sometimes wants to eat fruits with no encouragement, but sometimes she must encourage (54\% vs. $39 \%$ for villages, $47 \%$ for small towns).

The declared mothers at-home support of fruit and vegetable consumption stratified by the occupational status of mother is presented in Table 5. It was stated, that both for fruit $(\mathrm{p}=0.0008)$, and for vegetable consumption support $(\mathrm{p}=0.0181)$, the occupational status of mother was influencing factor. Both for fruit and vegetable consumption support, mothers with no professional job more commonly, than those with a professional job, declared lack of any support of consumption due to the fact that it is not needed ("child always wants to eat fruits/ vegetables with no encouragement") (fruits: $48 \%$ for no professional job vs. $35 \%$ for professional job; vegetables: $15 \%$ for no professional job vs. $11 \%$ for professional job). 
Table 3. Declared mothers at-home support of fruit and vegetable consumption stratified by the marital status of mother

\begin{tabular}{|c|c|c|c|c|}
\hline & Declared behaviour & $\begin{array}{c}\text { Married/ in a } \\
\text { married-like } \\
\text { relationship }(n=1072)\end{array}$ & $\begin{array}{c}\text { Single/ separated/ } \\
\text { divorced/ widowed } \\
(\mathrm{n}=128)\end{array}$ & p-Value* \\
\hline \multirow{5}{*}{$\begin{array}{l}\text { Mothers' at-home } \\
\text { support of fruit } \\
\text { consumption }\end{array}$} & $\begin{array}{l}\text { Child always wants to eat fruits with no } \\
\text { encouragement }\end{array}$ & $425(39.6 \%)$ & $48(37.5 \%)$ & \multirow{5}{*}{0.7483} \\
\hline & $\begin{array}{l}\text { Sometimes child wants to eat fruits with no } \\
\text { encouragement and sometimes I must encourage }\end{array}$ & $491(45.8 \%)$ & $60(46.9 \%)$ & \\
\hline & I always encourage child to eat fruits & $105(9.8 \%)$ & $12(9.4 \%)$ & \\
\hline & $\begin{array}{l}\text { Sometimes I encourage child to eat fruits and } \\
\text { sometimes I must even force }\end{array}$ & $36(3.4 \%)$ & $7(5.5 \%)$ & \\
\hline & I always force child to eat fruits & $15(1.4 \%)$ & $1(0.8 \%)$ & \\
\hline \multirow{5}{*}{$\begin{array}{l}\text { Mothers' at-home } \\
\text { support of } \\
\text { vegetable } \\
\text { consumption }\end{array}$} & $\begin{array}{c}\text { Child always wants to eat vegetables with no } \\
\text { encouragement }\end{array}$ & $123(11.5 \%)$ & $23(18.0 \%)$ & \multirow{5}{*}{0.2313} \\
\hline & $\begin{array}{l}\text { Sometimes child wants to eat vegetables with no } \\
\text { encouragement and sometimes I must encourage }\end{array}$ & $328(30.6 \%)$ & $38(29.7 \%)$ & \\
\hline & I always encourage child to eat vegetables & $406(37.9 \%)$ & $40(31.3 \%)$ & \\
\hline & $\begin{array}{l}\text { Sometimes I encourage child to eat vegetables and } \\
\text { sometimes I must even force }\end{array}$ & $159(14.8 \%)$ & $21(16.4 \%)$ & \\
\hline & I always force child to eat vegetables & $56(5.2 \%)$ & $6(4.7 \%)$ & \\
\hline
\end{tabular}

* assessed using $C h i^{2}$ test

At the same time, mothers with professional job more commonly than those with no job declared that child only sometimes wants to eat fruits or vegetables with no encouragement, but sometimes she must encourage (fruits: $50 \%$ for professional job vs. $38 \%$ for no professional job; vegetables: $33 \%$ for professional job vs. $25 \%$ for no professional job).

The declared mothers at-home support of fruit and vegetable consumption stratified by the total net income in household of mother is presented in Table 6. It was stated, that both for fruit $(\mathrm{p}=0.0000)$, and for vegetable consumption support $(\mathrm{p}=0.0272)$, the total net income in household of mother was influencing factor. Both for fruit and vegetable consumption support, mothers with the lowest total net income more commonly, than those with higher, declared lack of any support of consumption due to the fact that it is not needed ("child always wants to eat fruits/vegetables with no encouragement") (fruits: $52 \%$ for income $<2000$ PLN vs. $36 \%$ for income 2000 4000 PLN, $32 \%$ for income $>4000$ PLN; vegetables: $19 \%$ for income $<2000$ PLN vs. $10 \%$ for income 2000 4000 PLN, $11 \%$ for income $>4000$ PLN). At the same time, they less commonly than those with higher total net income declared that child only sometimes wants to eat fruits or vegetables with no encouragement, but sometimes she must encourage (fruits: $34 \%$ for income $<2000$ PLN vs. $47 \%$ for income $2000-4000$ PLN, $54 \%$ for income > 4000 PLN; vegetables: $26 \%$ for income $<$ 2000 PLN vs. $31 \%$ for income $2000-4000$ PLN, $32 \%$ for income $>4000$ PLN).

Table 4. Declared mothers at-home support of fruit and vegetable consumption stratified by the place of residence of mother

\begin{tabular}{|c|c|c|c|c|c|}
\hline & Declared behaviour & $\begin{array}{l}\text { Village } \\
(\mathrm{n}=501)\end{array}$ & $\begin{array}{l}\text { City of up } \\
\text { to } 100000 \\
\text { inhabitants } \\
(n=375)\end{array}$ & $\begin{array}{c}\text { City of above } \\
100000 \\
\text { inhabitants } \\
(\mathrm{n}=324) \\
\end{array}$ & p-Value* \\
\hline \multirow{5}{*}{$\begin{array}{l}\text { Mothers' at-home } \\
\text { support of fruit } \\
\text { consumption }\end{array}$} & $\begin{array}{l}\text { Child always wants to eat fruits with no } \\
\text { encouragement }\end{array}$ & $222(44.3 \%)$ & $151(40.3 \%)$ & $100(30.9 \%)$ & \multirow{5}{*}{0.0025} \\
\hline & $\begin{array}{l}\text { Sometimes child wants to eat fruits with no } \\
\text { encouragement and sometimes I must encourage }\end{array}$ & $198(39.5 \%)$ & $177(47.2 \%)$ & $176(54.3 \%)$ & \\
\hline & I always encourage child to eat fruits & $58(11.6 \%)$ & $28(7.5 \%)$ & $31(9.6 \%)$ & \\
\hline & $\begin{array}{l}\text { Sometimes I encourage child to eat fruits and } \\
\text { sometimes I must even force }\end{array}$ & $16(3.2 \%)$ & $13(3.5 \%)$ & $14(4.3 \%)$ & \\
\hline & I always force child to eat fruits & $7(1.4 \%)$ & $6(1.6 \%)$ & $3(0.9 \%)$ & \\
\hline \multirow{5}{*}{$\begin{array}{l}\text { Mothers' at-home } \\
\text { support of } \\
\text { vegetable } \\
\text { consumption }\end{array}$} & $\begin{array}{c}\text { Child always wants to eat vegetables with no } \\
\text { encouragement }\end{array}$ & $62(12.4 \%)$ & $50(13.3 \%)$ & $34(10.5 \%)$ & \multirow{5}{*}{0.5040} \\
\hline & $\begin{array}{l}\text { Sometimes child wants to eat vegetables with no } \\
\text { encouragement and sometimes I must encourage }\end{array}$ & $155(30.9 \%)$ & $113(30.1 \%)$ & $98(30.2 \%)$ & \\
\hline & I always encourage child to eat vegetables & $181(36.1 \%)$ & $147(39.2 \%)$ & $118(36.4 \%)$ & \\
\hline & $\begin{array}{l}\text { Sometimes I encourage child to eat vegetables and } \\
\text { sometimes I must even force }\end{array}$ & $73(14.6 \%)$ & $47(12.5 \%)$ & $60(18.5 \%)$ & \\
\hline & I always force child to eat vegetables & $30(6.0 \%)$ & $18(4.8 \%)$ & $14(4.3 \%)$ & \\
\hline
\end{tabular}


Table 5. Declared mothers at-home support of fruit and vegetable consumption stratified by the occupational status of mother

\begin{tabular}{|c|c|c|c|c|}
\hline & Declared behaviour & $\begin{array}{l}\text { Full-time/ part-time } \\
\text { job }(n=790)\end{array}$ & $\begin{array}{l}\text { No job declared } \\
(\mathrm{n}=410)\end{array}$ & p-Value* \\
\hline \multirow{5}{*}{$\begin{array}{l}\text { Mothers' at-home } \\
\text { support of fruit } \\
\text { consumption }\end{array}$} & $\begin{array}{c}\text { Child always wants to eat fruits with no } \\
\text { encouragement }\end{array}$ & $278(35.2 \%)$ & $195(47.6 \%)$ & \multirow{5}{*}{0.0008} \\
\hline & $\begin{array}{l}\text { Sometimes child wants to eat fruits with no } \\
\text { encouragement and sometimes I must encourage }\end{array}$ & $394(49.9 \%)$ & $157(38.3 \%)$ & \\
\hline & I always encourage child to eat fruits & $78(9.9 \%)$ & $39(9.5 \%)$ & \\
\hline & $\begin{array}{l}\text { Sometimes I encourage child to eat fruits and } \\
\text { sometimes I must even force }\end{array}$ & $28(3.5 \%)$ & $15(3.7 \%)$ & \\
\hline & I always force child to eat fruits & $12(1.5 \%)$ & $4(1.0 \%)$ & \\
\hline \multirow{5}{*}{$\begin{array}{l}\text { Mothers' at-home } \\
\text { support of } \\
\text { vegetable } \\
\text { consumption }\end{array}$} & $\begin{array}{c}\text { Child always wants to eat vegetables with no } \\
\text { encouragement }\end{array}$ & $85(10.8 \%)$ & $61(14.9 \%)$ & \multirow{5}{*}{0.0181} \\
\hline & $\begin{array}{l}\text { Sometimes child wants to eat vegetables with no } \\
\text { encouragement and sometimes I must encourage }\end{array}$ & $264(33.4 \%)$ & $102(24.9 \%)$ & \\
\hline & I always encourage child to eat vegetables & $291(36.8 \%)$ & $155(37.8 \%)$ & \\
\hline & $\begin{array}{c}\text { Sometimes I encourage child to eat vegetables and } \\
\text { sometimes I must even force }\end{array}$ & $112(14.2 \%)$ & $68(16.6 \%)$ & \\
\hline & I always force child to eat vegetables & $38(4.8 \%)$ & $24(5.9 \%)$ & \\
\hline
\end{tabular}

* assessed using $C h i^{2}$ test

Table 6. Declared mothers at-home support of fruit and vegetable consumption stratified by the total net income in household of mother

\begin{tabular}{|c|c|c|c|c|c|}
\hline & Declared behaviour & $\begin{array}{l}\text { Lower than } 2000 \\
\text { PLN }(\sim 450 €) \\
\quad(\mathrm{n}=307)\end{array}$ & $\begin{array}{c}2000-4000 \text { PLN } \\
(\sim 450-900 €) \\
(n=494)\end{array}$ & $\begin{array}{l}\text { Higher than } 4000 \\
\text { PLN }(\sim 900 €) \\
(\mathrm{n}=302)\end{array}$ & p-Value* \\
\hline & $\begin{array}{l}\text { Child always wants to eat fruits } \\
\text { with no encouragement }\end{array}$ & $160(52.1 \%)$ & $179(36.2 \%)$ & $97(32.1 \%)$ & \\
\hline Mothers' at-home & $\begin{array}{l}\text { Sometimes child wants to eat fruits with } \\
\text { no encouragement and sometimes I must } \\
\text { encourage }\end{array}$ & $103(33.6 \%)$ & $233(47.2 \%)$ & $162(53.6 \%)$ & 00000 \\
\hline consumption & I always encourage child to eat fruits & $30(9.8 \%)$ & $55(11.1 \%)$ & $27(8.9 \%)$ & \\
\hline & $\begin{array}{l}\text { Sometimes I encourage child to eat fruits } \\
\text { and sometimes I must even force }\end{array}$ & $10(3.3 \%)$ & $20(4.0 \%)$ & $13(4.3 \%)$ & \\
\hline & I always force child to eat fruits & $4(1.3 \%)$ & $7(1.4 \%)$ & $3(1.0 \%)$ & \\
\hline & $\begin{array}{l}\text { Child always wants to eat vegetables with } \\
\text { no encouragement }\end{array}$ & $57(18.6 \%)$ & $50(10.1 \%)$ & $33(10.9 \%)$ & \\
\hline Mothers' at-home & $\begin{array}{l}\text { Sometimes child wants to eat vegetables } \\
\text { with no encouragement and sometimes I } \\
\text { must encourage }\end{array}$ & $79(25.7 \%)$ & $152(30.8 \%)$ & $98(32.5 \%)$ & \\
\hline vegetable & I always encourage child to eat vegetables & $115(37.5 \%)$ & $180(36.4 \%)$ & $114(37.7 \%)$ & 0.0272 \\
\hline consumption & $\begin{array}{c}\text { Sometimes I encourage child to eat } \\
\text { vegetables and sometimes I must even } \\
\text { force }\end{array}$ & $43(14.0 \%)$ & $84(17.0 \%)$ & $40(13.2 \%)$ & \\
\hline & I always force child to eat vegetables & $13(4.2 \%)$ & $28(5.7 \%)$ & $17(5.6 \%)$ & \\
\hline
\end{tabular}

* assessed using $C h i^{2}$ test

\section{DISCUSSION}

In the presented own study conducted in a representative sample of Polish mothers of children aged 3-10, it was observed that neither age, nor marital status of mothers, influenced at-home support of fruit and vegetable consumption of their children. At the same time, for fruits, mothers with lower level of education, from villages and smaller towns, with no professional job and lower total net income in household, more commonly than others, stated, that no support of consumption is needed, as their children eat fruits with no encouragement, while other mothers stated that they sometimes must encourage. For vegetables, either the same situation as for fruits was observed (for mothers with no professional job and lower total net income in household), or mothers more commonly than others declared forcing children to consume (for mothers with the lowest level of education), while for place of residence of mother, no influence was stated.

In spite of the fact that in general, while three main age groups are compared (teen mothers, optimal age mothers and advanced age mothers), parenting practices are dependent on the maternal age [18], in the presented own study, such association was not observed. It results from the fact that not age at the moment of giving birth to a first child, but age at the moment of conducting research was assessed. Moreover, the main differences are stated while compared teen mothers with older ones, in terms of knowledge of child development, punitive attitudes 
toward childrearing, and level of depression [28], influencing general attitude, as teen mothers are less positive, less supportive, and less accessible to their children compared to non-teen mothers [18]. In the presented own study, the homogenic group of women aged 25-45 was assessed, so lack of significant differences may have been expected.

For single mothers, in general the mother-child relationships may differ from those for conjugal family, that is observed for both communication and involvement of mother [25]. However, in terms of diet, children of single mothers, even of low-income ones, are protected by them, as their mothers focus on providing them the adequate quality of diet [8]. It is associated with the fact that both single mothers and those from conjugal families have similar perspective of the role of family meals as a crucial element for the health and proper development, as well as opportunity for family communication and bonding [3].

However, for a number of assessed variables, the influence on the mothers at-home support of fruit and vegetable consumption was proven. The most important fact is associated with the specific groups of mothers for whom the unfavorable behaviors were stated - either forcing their children to consume vegetables, or ignoring need to encourage them to consume fruits or vegetables. It is rather improbable that in sub-groups almost majority of mothers or even majority of them declared that their child always wants to eat fruits with no encouragement, especially while the inadequate fruit and vegetable consumption in Polish children is commonly indicated [14]. The conclusion, that mothers rather ignore the need to encourage children to consume more fruits and vegetables, than really observe that they consume even with no encouragement, may be confirmed by commonly observed low level of agreement between parental and child reporting fruit and vegetable intake [27].

While there are indicated the specific groups of mothers vulnerable either to force child, but not enhance to consume fruits and vegetables, or to ignore the associated needs, they must be characterized. The low socioeconomic status mothers are in general at such risk, as they are: mothers with lower level of education, from villages and smaller towns, with no professional job and lower total net income in household. It is in agreement with the previous studies which indicated significant association between indicated factors and fruit or vegetable consumption. The Polish study proven association between the educational background of both parents and frequency of fresh fruit and vegetable consumption in case of their children, as the frequency was higher for a higher level of education [19]. The other Polish study revealed such association with the place of residence, as for children from the suburban areas, the intake was lower than for urban areas, even if it may had been supposed that fruit and vegetable availability is higher for suburban areas [13]. However, in the mentioned study [13], the other factor which may mediate for such a decreased consumption was indicated, namely - the food neophobia, being a significant factor associated with a fruit and vegetable intake [12]. The association between low income and fruit and vegetable consumption in families is in general observed and expected, as while the financial resources are reduced, they must be spent on other products [21], so such situation may influence not only the nutritional habits of parents but also of their children, while the intake of the most expensive products, such as fruits and vegetables must be reduced [29]. The other factor, being related to income, is the employment status, as for the unemployed parents, lower income is in general observed, so it may reduce the fruit and vegetable intake [26].

The indicated studies of other authors confirm the problem in the low socioeconomic status families, associated with possible lack of knowledge about recommended fruit and vegetable consumption, resulting in not encouraging children to consume, but in the opinion that they consume enough, as they in general like fruits and vegetables, as indicated in the presented own study.

However, not only the fruit and vegetable intake is in general associated with the indicated variables. It was also stated, that they may be associated with the parenting style associated with the nutritional behaviours of children, as parents who are unemployed and less acculturated report using controlling or authoritarian styles [1], which corresponds forcing children to eat fruits or vegetables reported in the presented own study.

Taking into account the improper nutritional behaviours of Polish children, that are observed for years [11], as well as the resultant excessive body mass [7], the further actions are necessary. It may be stated, that for the indicated groups of mothers the nutritional education is necessary, in order to provide them knowledge about the recommended fruit and vegetable intake, as well as recommended parenting style.

\section{CONCLUSIONS}

1. The socio-demographic status of mothers, especially level of education, place of residence, professional job and total net income, are important factors associated with their at-home support of fruit and vegetable consumption for their children.

2. The groups of mothers with lower level of education, from villages and smaller towns, with no professional job and lower total net income in household were indicated as important target 
groups to provide them knowledge about the recommended fruit and vegetable intake, as well as recommended parenting style.

\section{Acknowledgements}

This work was supported by the National Polish Promotion Fund for Fruits and Vegetables Consumption and Polish Association of Juices Producers within funds of the 5xVFJ (5 Portions of Vegetables, Fruit or Juice) national Polish campaign (Project of Agricultural Market Agency, no. PP/004/004/PP-1767/W/2011 financed within the Common Agricultural Policy (CAP), action: Support of promotion and information actions for agricultural products).

\section{Conflict of interest}

The authors declare no conflict of interest.

\section{REFERENCES}

1. Arredondo E.M., Elder J.P., Ayala G.X., Campbell N., Baquero B., Duerksen $S$. Is parenting style related to children's healthy eating and physical activity in Latino families? Health Educ Res 2006;21(6):862-871.

2. Aune D., Giovannucci E., Boffetta P., Fadnes L.T., Keum N., Norat T., Greenwood D.C., Riboli E., Vatten L.J., Tonstad S.: Fruit and vegetable intake and the risk of cardiovascular disease, total cancer and all-cause mortality-a systematic review and dose-response metaanalysis of prospective studies. Int J Epidemiol 2017; 1;46(3):1029-1056 doi: 10.1093/ije/dyw319.

3. Berge J.M., Hoppmann C., Hanson C., NeumarkSztainer D. Perspectives about family meals from single-headed and dual-headed households: a qualitative analysis. J Acad Nutr Diet 2013;113(12):1632-1639 doi:10.1016/j.jand.2013.08.023.

4. Breiner H., Ford M., Gadsden V.L. (editors). Parenting Matters: Supporting Parents of Children Ages 0-8. Washington (DC): National Academies Press (US); 2016 Nov 21. 2, Parenting Knowledge, Attitudes, and Practices. Available: https:/www.ncbi.nlm.nih.gov/ books/NBK402020 (Accessed 31 May 2019).

5. Czaja J., Rypina M., Lebiedzińska A. Ocena częstotliwości spożycia warzyw i owoców wśród studentów trójmiejskich uczelni [Consumption of fruit and vegetables among university and college students in Gdansk and Sopot]. Rocz Panstw Zakl Hig 2009;60(1): 35-38. (in Polish).

6. FAO/WHO Food and Agriculture Organization of the United Nations/ World Health Organization. Fruit and Vegetables for Health. Report of a Joint FAO/WHO Workshop, 1-3 September 2004, Kobe, Japan. Available http://www.fao.org/3/a-y5861e.pdf (Accessed 27 May 2019).

7. Głąbska D., Guzek D., Mellová B., Zadka K., Żywczyk K., Gutkowska K.: The National After-School Athletics Program Participation as a Tool to Reduce the Risk of Obesity in Adolescents after One Year of Intervention: A Nationwide Study. Int J Environ Res Public Health
2019;31:16(3).

8. Glanville N.T., McIntyre L.: Diet quality of Atlantic families headed by single mothers. Can J Diet Pract Res 2006;67(1):28-35.

9. Groele B., Gtąbska D., Gutkowska K., Guzek D.: Mother's Fruit Preferences and Consumption Support Similar Attitudes and Behaviors in Their Children. Int J Environ Res Public Health. 2018;12:15(12) doi:10.3390/ijerph15122833.

10. GroeleB., GtąbskaD., GutkowskaK., GuzekD.:Mothers' Vegetable Consumption Behaviors and Preferences as Factors Limiting the Possibility of Increasing Vegetable Consumption in Children in a National Sample of Polish and Romanian Respondents. Nutrients 2019;11(5):1078 doi.org/10.3390/nu11051078.

11. Gronowska-Senger A., Drywień M., Hamułka J. Analiza stanu żywienia dzieci w wieku przedszkolnym i szkolnym $\mathrm{w}$ oparciu o istniejące piśmiennictwo $\mathrm{z}$ lat 1980-1995 [Evaluation of food consumption and nutritional status of children at preschool and school age based on the literature in 1980-1995. Rocz Panstw Zakl Hig 1998;49(3):377-383.

12. Guzek D., Głąbska D., Lange E., Jezewska-Zychowicz $M$. A Polish Study on the Influence of Food Neophobia in Children (10-12 Years Old) on the Intake of Vegetables and Fruits. Nutrients 2017;9(6):563. doi:10.3390/ nu9060563

13. Guzek D., Głąbska D., Mellová B., Zadka K., Żywczyk K., Gutkowska K.: Influence of Food Neophobia Level on Fruit and Vegetable Intake and Its Association with Urban Area of Residence and Physical Activity in a Nationwide Case-Control Study of Polish Adolescents. Nutrients 2018;10(7):897. doi:10.3390/nu10070897.

14. Ilow R., Plonka K., Regulska-Ilow B., Biernat J. Assessment of fruit and vegetable intake among the population of junior high school students from Oleśnica. Rocz Panstw Zakl Hig 2007; 58(1): 237-243.

15. Ilow R., Regulska-Ilow B., Misiewicz D., Różańska D., Kowalisko A., Biernat J. Ocena spożycia warzyw i owoców w grupie 50-letnich mieszkańców Wrocławia [Assessment of fruit and vegetable intake among the 50-year-old population of Wroclaw]. Rocz Panstw Zakl Hig 2011, 62(3): 301-306. (in Polish).

16. Ilow R.A., Regulska-Ilow B., Różańska D. Dietary habits of Wroclaw Medical University students (Poland) Rocz Panstw Zakl Hig 2017;68(1):23-32.

17. Jones L.R., SteerC.D., RogersI.S.,EmmettP.M. Influences on child fruit and vegetable intake: sociodemographic, parental and child factors in a longitudinal cohort study. Public Health Nutr. 2010;13(7):1122-1130; doi: $10.1017 / \mathrm{S} 1368980010000133$.

18. Kim T.H.M., Connolly J.A., Rotondi M., Tamim H. Characteristics of positive-interaction parenting style among primiparous teenage, optimal age, and advanced age mothers in Canada. BMC Pediatr 2018;18(1):2; doi:10.1186/s12887-017-0972-z.

19. Kwiatkowska E.: Wpływ wykształcenia rodziców na częstotliwość spożywania warzyw i owoców przez ich dzieci [Influence of the parents education of the frequency of vegetable and fruit consumption by their 
children. Rocz Panstw Zakl Hig 2010;61(2):179-182.

20. Lee-Kwan S.H., Moore L.V., Blanck H.M., Harris D.M., Galuska D. Disparities in State-Specific Adult Fruit and Vegetable Consumption - United States, 2015. MMWR Morb Mortal Wkly Rep. 2017;17;66(45), 1241-1247 doi:10.15585/mmwr.mm6645a1.

21. Mackenbach J.D., Brage S., Forouhi N.G., Griffin S.J., Wareham N.J., Monsivais P. Does the importance of dietary costs for fruit and vegetable intake vary by socioeconomic position? Br J Nutr 2015;114(9):14641470. doi:10.1017/S0007114515003025.

22. Nekitsing C., Hetherington M.M., Blundell-Birtill P. Developing Healthy Food Preferences in Preschool Children Through Taste Exposure, Sensory Learning, and Nutrition Education. Curr Obes Rep 2018;7(1):6067 doi:10.1007/s13679-018-0297-8.

23. NHS. National Health Service. Why 5 A Day? Available: https://www.nhs.uk/live-well/eat-well/why-5-a-day/ (Accessed 31 May 2019).

24. Pem D., Jeewon R. Fruit and Vegetable Intake: Benefits and Progress of Nutrition Education Interventions - Narrative Review Article. Iran J Public Health 2015;44(10):1309-1321.

25. Ramsey M., Gitimu-Waithaka A., Gitimu P.N. Youngstown State University Influence of Age and Parental Marital Status on Parent-Child Relationships: College Students Perspective. Intern J Human Soc Sci 2016;6;1:23-32.

26. Rasmussen M., Krølner R., Klepp K.I., Wind M., Due $P$. Determinants of fruit and vegetable consumption among children and adolescents: a review of the literature. Part I: Quantitative studies. Int J Behav Nutr Phys Act. 2006;3:22. doi:10.1186/1479-5868-3-22.
27. Reinaerts E., de Nooijer J., de Vries N.K. Parental versus child reporting of fruit and vegetable consumption. Int J Behav Nutr Phys Act. 2007;4:33. doi:10.1186/14795868-4-33.

28. Reis $J$. A comparison of young teenage, older teenage, and adult mothers on determinants of parenting. J Psychol 1989;123(2):141-151.

29. Riediger N.D., Shooshtari S., Moghadasian M.H. The influence of sociodemographic factors on patterns of fruit and vegetable consumption in Canadian adolescents. J Am Diet Assoc 2007;107(9):1511-1158.

30. Sharps M., Robinson E. Encouraging children to eat more fruit and vegetables: Health vs. descriptive social norm-based messages. Appetite 2016;100:18-25 doi:10.1016/j.appet.2016.01.031.

31. Vaughn A.E., Ward D.S., Fisher J.O., Faith M.S., Hughes S.O., Kremers S.P., Musher-Eizenman D.R., O'Connor T.M., Patrick H., Power T.G. Fundamental constructs in food parenting practices: a content map to guide future research. Nutr Rev 2016;74(2):98-117 doi:10.1093/nutrit/nuv061.

32. WHO. World Health Organization. Comparative analysis of nutrition policies in the WHO European Region, A comparative analysis of nutrition policies and plans of action in WHO European Available: http://www.euro. who.int/_data/assets/pdf_file/0004/149782/instanbul_ conf_20ebd02.pdf (Accessed 31 May 2019).

33. WHO. World Health Organization. Promoting fruit and vegetable consumption around the world. Available: https://www.who.int/dietphysicalactivity/fruit/en/ (Accessed 31 May 2019).

Received: 10.06 .2019

Accepted: 25.06.2019

This article is available in Open Access model and licensed under a Creative Commons Attribution-Non Commercial 3.0.Poland License (CC-BY-NC) available at: http://creativecommons.org/licenses/by-nc/3.0/pl/deed.en 